\title{
PRIMARY MEASURES FOR THE REDUCTION OF NOX EMISSIONS FROM IRON ORE SINTERING - A REVIEW
}

\author{
Christof LANZERSTORFER, Andreas GAHLEITNER
}

University of Applied Sciences Upper Austria, Wels, Austria, EU, c.lanzerstorfer@fh-wels.at

https://doi.org/10.37904/metal.2019.667

\begin{abstract}
During the sintering of iron ore in the sintering process, nitrogen oxides (NOx) are produced and discharged with the process off-gas. The reported concentrations of nitrogen oxides expressed as $\mathrm{NO}_{2}$ in sintering off-gas are typically in the range of $300-500 \mathrm{mg} / \mathrm{Nm}^{3}$. However, also concentrations up to $1000 \mathrm{mg} / \mathrm{Nm}^{3}$ have been reported. NOx emissions from combustion can originate from three different formation mechanisms: thermal NOx, prompt NOx and fuel NOx. It has been established that in the sintering process the most significant source of NOx emissions is the fuel NOx. According to literature, only a few iron ore sinter plants operate a DeNOx system for the reduction of the NOx emissions (Secondary measures). However, there is plenty of ongoing research in primary measures for the reduction of the NOx emissions from the sintering process. These measures include the recirculation of the process off-gas, pre-treatment of the coke breeze used as fuel, replacement of the coke breeze by other fuels and the addition of various compounds to the sinter feed for the reduction of the NOx formation. In this study, the data available in the literature about the primary measures for the reduction of the NOx emissions from iron ore sinter plants are summarized, compared and discussed.
\end{abstract}

Keywords: Sintering process, NOx emission, primary measures, emission reduction

\section{INTRODUCTION}

In the sintering process the feed material - a mixture of fine grained iron ore, flux, recycled fines and a solid fuel, usually coke breeze - is granulated and subsequently placed on a continuous traveling grate, the sinter strand. A burner at the beginning of the strand ignites the fuel contained in the mixture, after which the combustion is self-supporting. Beneath the grate there are several windboxes to draw air and combustion gases through the sintering bed. The combustion of the coke which accounts for approximately 4-6 \% of the charge generates sufficient heat $\left(1300-1480{ }^{\circ} \mathrm{C}\right)$ to sinter the fine particles into a porous sinter. The off-gas from the sinter strand which is typically in the range of $1500-2500 \mathrm{Nm}^{3}$ per tonne of sinter produced contains considerable quantities of entrained particles and various gaseous pollutants. Therefore, it has to be cleaned before it is released into the atmosphere via the main stack [1].

In the combustion zone nitrogen oxides (NOx) are produced and discharged with the process off-gas. The reported concentrations of $\mathrm{NOx}$ expressed as $\mathrm{NO}_{2}$ in sintering off-gas are typically in the range of 300$500 \mathrm{mg} / \mathrm{Nm}^{3}$, but also concentrations up to $1000 \mathrm{mg} / \mathrm{Nm}^{3}$ have been reported. The NOx emitted consists mainly of $\mathrm{NO}$ and only a small fraction is present as $\mathrm{NO}_{2}$. The dominating source for $\mathrm{NOx}$ is the nitrogen contained in the coke breeze $[1,3]$. Since the NOx emissions from sinter plants account for approximately half of the total NOx emissions from the iron and steel industry reduction of the emissions from sinter plants is of great imprtance [2].

In general, the emissions limits for sinter plants have been tightened in recent years. For Europe the Best Available Technique Associated Emission Levels (BAT-AELs) for air emissions from sinter plants are defined in the commission implementing decision of 28 February 2012 [4], which establishes the best available techniques (BAT) conclusions under Directive 2010/75/EU of the European Parliament and of the Council on industrial emissions for the iron and steel production [5]. The defined BAT-AELs depend on the BAT technology 
applied for emission reduction, while in contrast, fixed emission limits are valid in China [6]. Table 1 shows the current NOx emission limits for sinter plants in Europe and China [4-6].

Table 1 Emission limits for NOx for iron ore sinter plants

\begin{tabular}{|l|c|c|}
\hline & Europe [4,5] ${ }^{*}$ & China [6] \\
\hline \begin{tabular}{l|l|} 
Off-gas recirculation, \\
Low NOx burner for ignition
\end{tabular} & $500 \mathrm{mg} / \mathrm{Nm}^{3} \mathrm{dry}$ & \\
\cline { 1 - 2 } Regenerative activated carbon process & $250 \mathrm{mg} / \mathrm{Nm}^{3} \mathrm{dry}$ \\
\cline { 1 - 2 } Selective catalytic reduction (SCR) & $120 \mathrm{mg} / \mathrm{Nm}^{3} \mathrm{dry}$ & \\
\hline
\end{tabular}

* daily mean value related to an oxygen content of $15 \%$

\section{OFF-GAS RECIRCULATION}

The partial recirculation of off-gas is an efficient technique for reducing the amount of exhaust gas from a sinter plant discharged through the main stack $[1,7]$. Such recirculation is possible because of the high oxygen content of off-gas from conventional sintering of about $15 \%$, while the minimum oxygen content for sintering is in the range of $9-13 \%[1,8]$. Therefore, the maximum possible degree of recirculation depends on the oxygen content of the off-gas when no off-gas is recirculated. The published results show that the increase in the NOx concentration of the off-gas is small compared to the reduction of the off-gas volume, which leads to a net reduction of the NOx emissions [9-11]. Additionally, the sinter off-gas contains about $1 \% \mathrm{CO}$, which is oxidized when the recirculated gas passes through the flame front in the sinter bed. Thus, off-gas recirculation also reduces the fuel consumption in the sinter process, which further reduces the NOx emissions.

There are several process designs in use for off-gas recirculation in sinter plants at industrial scale. In the EOS system, part of the exhaust gas collected in the windboxes is returned after dedusting to a hood covering the entire sinter strand [9]. In other designs (NSC system [10], LEEP system [11] and Eposint system [12]) selective off-gas recirculation is applied, where the off-gas from selected windboxes is returned to hoods, which are located over certain parts of the sinter strand. Table 2 shows the published NOx reduction data for the different systems.

Table 2 Reported emission reduction achieved with various off-gas recirculation systems

\begin{tabular}{|l|l|c|c|c|c|}
\hline & & EOS [9] & NSC [10] & LEEP [11] & Eposint [12] \\
\hline Off-gas volume & $\mathrm{m}^{3} / \mathrm{h}$ & $-47 \%$ & $-28 \%$ & $-45 \%$ & $-40 \%$ \\
\hline NOx emission & $\mathrm{kg} / \mathrm{h}$ & $-39 \%$ & $-31 \%$ & $-49 \%$ & $-24 \%$ \\
\hline
\end{tabular}

\section{SUBSTITUTION OF COKE BREEZE OR PRETREATMENT}

\subsection{Substitution of coke breeze}

Since most of the emitted NOx originates from fuel nitrogen the substitution of coke breeze by a fuel with a low nitrogen content can reduce the NOx emissions.

In a study using charcoal at different rates in sinter pot tests for the substitution of coke the equivalent fixed carbon substitution method was applied [16]. Because of the higher content of volatiles in the charcoal the energy input was increased using the substitution method. Up to a substitution rate of $60 \%$ the sintering process parameters were not deteriorated, while according to the diagrams the NOx emissions decreased almost linear with increasing coke substitution. However, no detailed data for the NOx reduction were reported.

In another study, the use of charcoal, charred-straw and molded-sawdust was investigated in sinter pot tests [17]. The substitution was performed on an equivalent heat basis. The process parameters and the quality of 
the sinter produced were nearly unchanged up to coke substitution rates of $40 \%, 20 \%$ and $15 \%$ for charcoal, charred-straw and molded-sawdust. The respective reductions of NOx emissions were $26.8 \%, 18.3 \%$ and $15.5 \%$.

In an investigation about straw-based fuels in sintering the limits for the use of straw char and preformed straw char resulting from process and sinter quality parameters were $20 \%$ and $40 \%$ substitution on an equivalent heat basis, respectively [18]. The corresponding reductions of NOx emissions were $16.9 \%$ and $28.2 \%$.

\subsection{Pretreatment of the coke breeze}

The NOx emissions from the sintering process can be reduced by pretreatment of the coke breeze. In a study, sinter pot tests were performed where the coke was modified with $\mathrm{CeO}_{2}$ prior to its use. Fine grained $\mathrm{CeO}_{2}$ powder in the range of 28-150 $\mu \mathrm{m}$ was added into water to make a suspension with a certain concentration. The coke was impregnated in the $\mathrm{CeO}_{2}$ suspension and subsequently dried. The $\mathrm{CeO}_{2}$ content of the coke was up to $2.0 \%$. At the highest $\mathrm{CeO}_{2}$ content an emission reduction for NOx of $18.8 \%$ was observed [13].

In another study, the preparation of the coke breeze was performed with a solution of urea [14]. The highest NOx reduction $(16.2 \%)$ was achieved at $1.0 \%$ urea content of the coke, while at higher urea concentrations of the coke the NOx emissions were increased.

The combination of off-gas recirculation and use of impregnated coke for the reduction of NOx emissions was investigated in sinter pot tests [15]. Thereby, the coke was modified with $\mathrm{CeO}_{2}, \mathrm{~K}_{2} \mathrm{CO}_{3}$ or $\mathrm{CaO}$ prior to its use. The reduction of $\mathrm{NOx}$ emissions using coke loaded with $\mathrm{CeO}_{2}, \mathrm{~K}_{2} \mathrm{CO}_{3}$ or $\mathrm{CaO}$ was in the range of $34-38 \%$, which was approximately $10 \%$ higher than in the reference test with off-gas recirculation only.

\subsection{Pretreatment of the sinter feed}

The NOx emissions can be influenced by the distribution of the fuel in the sinter feed. During preparation of the sinter feed the blended fine materials including iron ores, fluxes, return fine and coke breeze are granulated at suitable moisture to improve the permeability of the sinter mixture. In a laboratory study double-layered granules were produced by pre-granulation of all the coke breeze, part of the iron ores and fluxes in a first step. The rest of the iron ores and fluxes as well as the return fines were added in the second granulation step [2]. Thus, the structure of the granules was divided into two layers: the inner layer containing the all the coke breeze and the outer layer consisting of iron ores and fluxes. Since the fuel was wrapped inside the granules it was not directly exposed to air and, therefore, needed more time to burn out. The $\mathrm{O}_{2}$ concentration in the atmosphere of the inner layer is comparatively low, which reduces the conversion of fuel nitrogen to NOx. As a result, the NOx emissions were reduced. In the study a $25 \%$ reduction of NOx emission was reported [2].

\section{ADDITION OF NOX-REDUCING AGENTS}

The addition of calcium ferrite into the sinter feed mixture is proposed to reduce NOx emissions since calcium ferrite enhances the catalytic reaction of $\mathrm{CO}$ with $\mathrm{NO}$ in the sintering bed [19]. Additionally, the strength of the sinter will be improved with the help of calcium ferrite because of its low melting point. The results of sinter pot tests showed a reduction of NOx emissions of $26.8 \%$ compared to conventional sintering at $8 \%$ addition of calcium ferrite, which was the optimum rate. At higher calcium ferrite addition the permeability of sintering bed was significantly reduced.

The addition of $1.0 \%$ rice husk, flour, saw dust or cane slag to the sinter feed mixture showed little potential for NOx emission reduction and eventually decreased the productivity [20]. In contrast, the addition of $1.0 \%$ sugar led to a reduction of NOx emissions of $28 \%$. Additionally, the productivity was somewhat increased. 


\section{CONCLUSION}

Primary reduction of NOx emissions from iron ore sintering can be achieved by various methods: off-gas recirculation, substitution or pretreatment of coke as fuel or addition of NOx-reducing agents. However, only off-gas recirculation is applied on an industrial scale. The performance of the other primary reduction methods was reported only for pilot scale tests. Future efforts would be required to demonstrate the performance of these methods on full-scale plants.

The highest reduction rates for NOx emissions are reported for off-gas recirculation (24-49\%), followed by substitution of coke by charcoal or straw char (16.9 up to approximately $40 \%$ ). The addition of NOx-reducing agents (26.8-28 \%), the substitution of coke by other organic material (15.5-18.3\%) and pretreatment (16.6$25 \%$ ) shows less NOx reduction potential.

\section{ACKNOWLEDGEMENTS}

The study was financially supported by K1-MET. K1-MET is a member of COMET - Competence Centers for Excellent Technologies and is financially supported by the BMVIT (Federal Ministry for Transport, Innovation and Technology), BMWFJ (Federal Ministry of Economy, Family and Youth), the federal states of Upper Austria, Styria and Tyrol, SFG and Tiroler Zukunftsstiftung. COMET is managed by FFG (Austrian research promotion agency).

\section{REFERENCES}

[1] REMUS, Rainer, AGUADO-MONSONET, Miguel A., ROUDIER, Serge and SANCHO, Luis D. Best Available Techniques (BAT) Reference Document for Iron and Steel Production, Industrial Emissions Directive 2010/75/EU, Integrated Pollution Prevention and Control. Luxembourg: Publications Office of the European Union, 2013.

[2] GAN, Min, FAN, Xiaohui, LV, Wei, CHEN, Xuling, JI, Zhiyun, JIANG, Tao, YU, Zhiyuan and ZHOU, Yang. Fuel pre-granulation for reducing NOX emissions from the iron ore sintering process. Powder Technology. 2016. vol. 301, pp. 478-485.

[3] HU, H., HUANG, H., ZENG, Z.W., ZHANG, J.L., ANNANUROV, S. and ZHAO, Q.Z. The formation of NOx during sintering. Energy Sources, Part A: Recovery, Utilization, and Environmental Effects. 2017. vol. 39, no. 12, pp. 1228-1234.

[4] European Commission. Commission implementing decision of 28 February 2012 establishing the best available techniques (BAT) conclusions under Directive 2010/75/EU of the European Parliament and of the Council on industrial emissions for iron and steel production. Notified under document C(2012) 903, (2012/135/EU), 2012.

[5] European Parliament and Council of the European Union. Directive 2010/75/EU of the European Parliament and of the Council of 24 November 2010 on industrial emissions (integrated pollution prevention and control. (2010)

[6] Ministry of environmental protection of the people's republic of China. Emission standard of air pollutants for sintering and pelletizing of iron and steel industry. GB28662-2012, 2012.

[7] LANZERSTORFER, Christof. State of the Art in Air Pollution Control for Sinter Plants. In: CAVALIERE, Pasquale, ed. Ironmaking and Steelmaking Processes. Cham: Springer, 2016, pp. 301-319.

[8] MÜHLBÖCK, Marlene, NADERER, Gerald, FEHRINGER, Edmund. Recirculation of sinter off gas - a selective approach. In $45^{\circ}$ Ironmaking $/ 16^{\circ}$ Iron Ore $/ 3^{\circ}$ Agglomeration Conference. Rio de Janeiro, 2015. Pp. 154-163. Available from: DOI: 10.5151/4444-4444-26279

[9] LEUWERINK, Theo and VAN DER PANNE, Albert. Operation results of emission optimized sintering with Airfine gas cleaning. Stahl und Eisen. 2001. vol. 121, no. 5, pp. 29-34.

[10] SAKURAGI, J, KUBO, S, TERADA, J and MOCHIDA J. Operation results of the exhaust gas recirculation system in Tobata No. 3 sinter plant. Revue Metallurgie-CIT. 1994. vol. 94, no. 6, pp. 899-908.

[11] BASTÜRK, Süleyman, DELWIG, Christoph, EHLER, Wolfram, HARTIG, Walter, HILLMANN, Carsten, LÜNGEN, Hans Bodo, RICHTER, Jörg, SCHNEIDER, Henning and ZIRNGAST, Johann. Technologien und Trends zur Abgasreinigung an Sinteranlagen. Stahl und Eisen. 2009. vol. 129, no. 5, pp. 51-59. 
[12] REIDETSCHLÄGER, Johann, STIASNY, Hans, HÖTZINGER, Stefan, AICHINGER, Christoph, FULGENCIO, André. Selective waste gas recirculation system for sintering plants. Stahl und Eisen. 2012. vol. 132, no. 1, pp. 25-30.

[13] CHEN, Yan-guang, GUO, Zhan-cheng and WANG, Zhi. Influence of $\mathrm{CeO}_{2}$ on NOx emission during iron ore sintering. Fuel Processing Technology. 2009. vol. 90, no. 7-8, pp. 933-938.

[14] FAN, Xiao-hui, YU, Zhi-yuan, GAN, Min, CHEN, Xu-ling, HUANG, Yun-song, JIANG, Tao and LI, Guanghui. Research on NOx reduction by applying coke breeze pre-treated with urea additive in iron ore sintering process. In: BATTLE, Thomas P., DOEWNEY, Jerome P., MAY, Lawrence D., DAVIS, Boyd, NEELAMEGGHAM, Neale R., SANCHEZ-SEGADO, Sergio and PISTORIUS, P. Chris, eds. Drying, Roasting and Calcining of Minerals. Cham: Springer, 2015, pp. 269-276.

[15] CHEN, Yan-guang, GUO, Zhan-cheng and WANG, Zhi. Application of Modified Coke to NOx Reduction with Recycling Flue Gas during Iron Ore Sintering Process. ISIJ International. 2008. vol. 48, no. 11, pp. 1517-1523.

[16] CHENG, Zhilong, YANG, Jian, ZHOU, Lang, LIU, Yan, GUO, Zhigang and WANG, Qiuwang. Experimental study of commercial charcoal as alternative fuel for coke breeze in iron ore sintering process. Energy Conversion and Management. 2016. vol. 125, pp. 254-263.

[17] GAN, Min, FAN, Xiaohui, CHEN, Xuling, JI, Zhiyun, LV, Wei, WANG, Yi, YU, Zhiyuan and JIANG, Tao. Reduction of Pollutant Emission in Iron Ore Sintering Process by Applying Biomass Fuels. ISIJ International. 2012. vol. 52, no. 9, pp. 1574-1578.

[18] FAN, Xiaohui, JI, Zhiyun, GAN, Min, CHEN, Xuling and JIANG, Tao. Integrated assessment on the characteristics of straw-based fuels and their effects on iron ore sintering performance. Fuel Processing Technology. 2016. Vol. 150, pp. 1-9.

[19] YU, Zhi-yuan, FAN, Xiao-hui, GAN, Min, CHEN, Xu-ling. Effect of Ca-Fe oxides additives on NOx reduction in iron ore sintering. Journal of Iron and Steel Research, International. 2017. vol. 24, pp. 1184-1189.

[20] MO, Chin-Lu, TEO, Cher-Son, HAMILTON, lan and MORRISON, John. Admixing Hydrocarbons in Raw Mix to Reduce NOx Emission in Iron Ore Sintering Process. ISIJ International. 1997. vol 37, no. 4, pp. 350-357. 